二神枝保

\section{SDGs とジェンダー平等}

現在、持続可能な開発目標 (SDGs: Sustainable Development Goals）の追求は、世界的潮流と なっている。SDGsは、2015年9月に開催され た国連サミットで採択された17の国際目標であ る。そこでは、誰一人取り残さないことを誓っ ており、包摂的な社会（inclusive societies）の実 現を決意している (United Nations, 2015)。目標 のひとつは、ジェンダー平等を実現し、すべて の女性と女児のエンパワーメントを行うことで ある。ジェンダー平等 (gender equality) は、持 続可能な開発に不可欠なキーワードであり、重 要な概念になっている。

日本のSDGs達成度は、2020年に世界166か 国中17位であるが、ジェンダー平等は最大の課 題のひとつになっている。とくに、国会議員に 占める女性比率、男女賃金格差、家事・育児な ど無償労働時間の男女格差に重要な課題がある と指摘される (Sachs et al., 2020)。

Global Gender Gap Report 2020 (World Economic Forum, 2019）によれば、男女格差を 測るグローバル・ジェンダー・ギャップ指数に

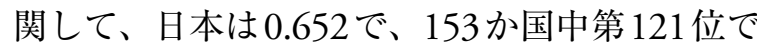
ある。とくに、政治分野では0.049で第144位、 経済分野では0.598で第115位であり、ジェン ダー平等が実現されていない（Futagami, 2010;
Futagami et al., 2017; 二神、2020b)。

\section{学術分野におけるジェンダー平等}

学術分野でジェンダー平等は実現されている だろうか。「科学技術研究調査」（総務省、2019） によれば、日本の女性研究者数は 155,000 人で、 女性研究者比率は、16.6\%である。ラトビア $50.7 \%$ 、ノルウェー38.8\%、英国38.6\%、フィ ンランド $33.7 \%$ 等ヨーロッパ諸国のそれと比較 すると、日本の女性研究者比率は低い (OECD, 2018)。

「令和元年度学校基本調査」（文部科学省、 2019）によれば、大学の職位でみると、講師にお ける女性比率は $32.9 \%$ 、准教授における女性比 率は $25.1 \%$ 、教授における女性比率は $17.4 \%$ 、副 学長における女性比率は $12.3 \%$ 、学長における 女性比率は $11.9 \%$ と職位が上がるにつれて低い。 指導的地位の女性研究者の活躍も課題である。

\section{日本の低い女性研究者比率と指導的 地位の女性研究者比率 一理由と改善策}

日本学術会議第一部総合ジェンダー分科会と 人文社会科学系学協会男女共同参画推進連絡会 （GEAHSS）は、2018年6月から 11月末に人文 社会科学系学協会会員を対象にアンケート調査 


\section{PROFILE}

二神枝保 (ふたがみ しほ)

曰日本学術会議連携会員

口横浜国立大学大学院国際社会科学研究院教授

京都大学経済学博士

・チューリッヒ大学客員教授

- ILO (国際労働機関) 客員教授

專門 経営学、人的資源管理

を実施した。回収票数は2,972であった。筆者 は、調查分析委員会のメンバーとして分析を行 い、女性研究者比率および指導的地位の女性研 究者比率が低い理由やその改善策について、以 下の点を明らかにしている。

第一に、女性研究者比率および指導的地位の 女性研究者比率が低い理由として、「家庭と仕事 の両立が困難」は最も多い回答であり、女性研 究者にとって、ワークライフバランス支援策が 重要な課題といえる（二神、2020a；2020b）。こ の点は、「科学研究者の環境に関する調査」(科 学研究者の環境に関する調査研究会、1997）で も既に指摘されたが、同調査から 20 年以上経っ た今でも解決されていない。「第四回科学技術系 専門職の男女共同参画実態調査」(男女共同参画
学協会連絡会、2017）でも、理系の女性研究者 が少ない理由として、「家庭と仕事の両立が困 難」が上位であり、ワークライフバランス支援 策は文系、理系を問わず早急に解決すべき課題 である。したがって、労働時間管理施策や託児・ 保育施設等支援体制の充実が急務である。

第二に、女性研究者比率が低い現状の改善策 として、「女性の優先採用」や「役職・管理職へ の登用」、「業績評価におけるライフイベント等 の考慮」が多い回答である。つまり、女性研究 者の活躍を推進するには、女性研究者の積極的 な採用・配置・昇進・業績評価といった一連の 体系的な人的資源管理プログラムが不可欠とい える (二神、2020a; 2020b)。フランス大学長会 議 (CPU) が提言するように、クオータ制によっ

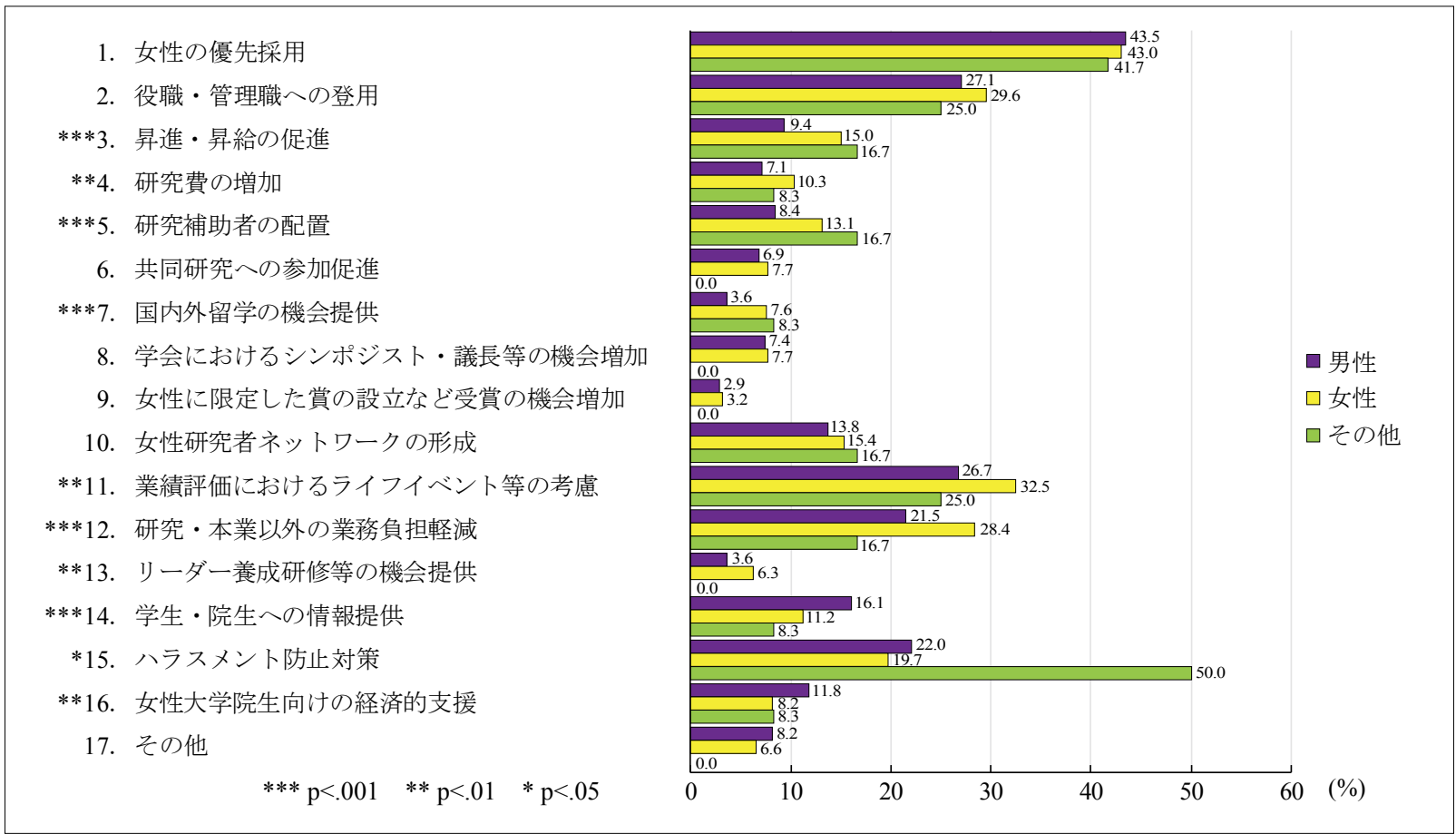

図1 女性研究者比率が低い現状の改善策: 性別ごとの検定結果 出所：二神 (2020a).

（注）アンケート調査では、自認によって性別を回答している。性別は、全体 2,972 名のうち、男性 1,384 名 $(46.6 \%$ )、女性 1,576 名 (53.0\%)、その他 12 名 $(0.4 \%)$ である。 
**1. 女性の優先採用

***2. 役職・管理職への登用

3. 昇進・昇給の促進

*4. 研究費の増加

5. 研究補助者の配置

6. 共同研究への参加促進

**7. 国内外留学の機会提供

***8. 学会におけるシンポジスト・議長等の機会増加

9. 女性に限定した賞の設立など受賞の機会増加

*10. 女性研究者ネットワークの形成

***11. 業績評価におけるライフイベント等の考慮

12. 研究・本業以外の業務負担軽減

**13. リーダー養成研修等の機会提供

***14. 学生・院生への情報提供

15. ハラスメント防止対策

16. 女性大学院生向けの経済的支援

17. その他

*** $\mathrm{p}<.001 \quad * * \mathrm{p}<.01 \quad * \mathrm{p}<.05$

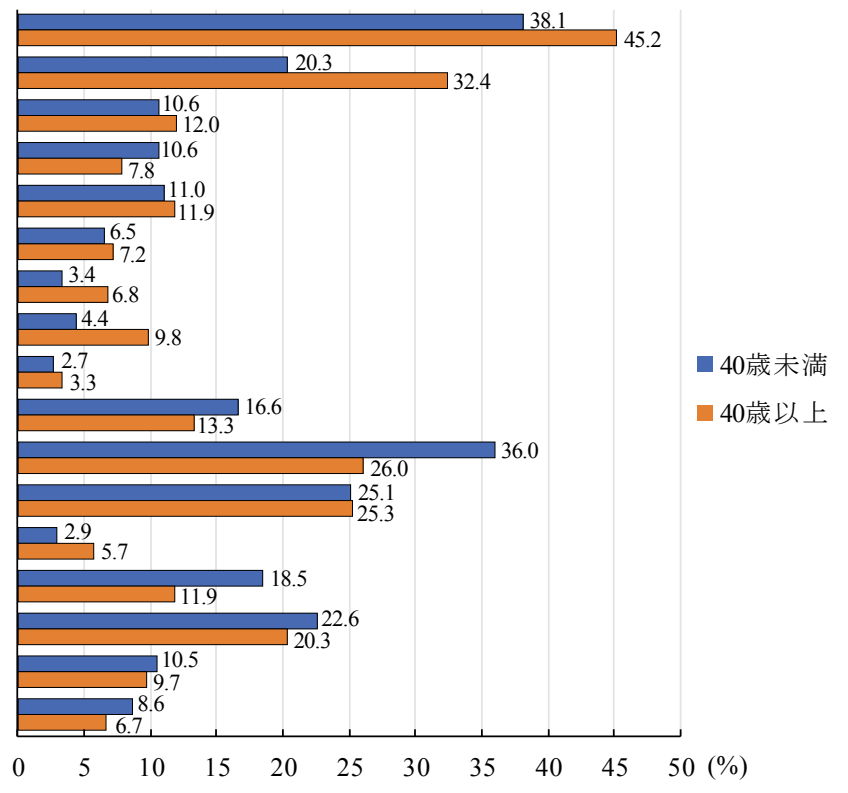

図2 女性研究者比率が低い現状の改善策：年齢別の検定結果 出所 : 二神 (2020a).

て女性研究者を積極的に採用することはもちろ ん重要であるが、採用のみならず、女性研究者 が長期的に組織に定着し、成長し、ライフサイ クルに沿って活躍できるような配置や人材開発、 業績評価も同様に大切である。

第三に、女性研究者比率が低い現状の改善策 について、性別や年齢によって意識に違いがあ る。図 1 は、女性研究者比率が低い現状の改善 策について、性別ごとにカイ2乗検定した結果 である。これによると、男性では、女性に比べ て「学生・院生への情報提供」や「女性大学院生 向けの経済的支援」と回答する比率が有意に高 い。これは、女性研究者になるためのキャリア・ ガイダンスや奨学金など経済的支援の重要性を 指摘するものである。他方、女性では、男性に 比べて「業績評価におけるライフイベント等の
考慮」と回答する比率が有意に高い。これは、 女性研究者の方が男性研究者よりも育児や介護 等のライフイベントによって現状では影響を受 けやすく、その際の業績評価のあり方に関心が 高いためだろう。

図2は、女性研究者比率が低い現状の改善策 について、年齢別にカイ2乗検定した結果であ る。これによると、40歳以上では、40歳未満 に比べて「女性の優先採用」や「役職・管理職へ の登用」と回答する比率が有意に高い。これは、 40 歳以上の研究者の方が、40歳未満の研究者よ りも採用や登用においてジェンダー不平等を経 験していることから、女性の積極的採用や登用 を改善策として重要視していると解釈できる。 他方、40歳未満では、40歳以上に比べて「業績 評価に拀けるライフイベント等の考慮」と回答 
する比率が有意に高い。これは、40歳未満の研 究者の方が、業績評価において育児等への配慮 は大切であると考えているためだろう。したがっ て、性別や年齢による意識の違いにも配慮しな がら、女性研究者の活躍を推進していく必要が ある（二神、2020a; 2020b）。

\section{女性研究者の活躍推進によって もたらされるもの}

女性研究者の活躍を推進することによって、 どのような成果を導くだろうか。

日本の男性の論文発表数（2014-2018年）は 5.92で、女性の3.29よりも多く、男性は女性の 約 1.8倍論文を発表している（Elsevier, 2020）。 しかし、同時期の女性の FWCI（被引用数によ る研究のインパクト指標）は、0.699で、男性 の0.720 と男女差はほとんどみられない。1999-

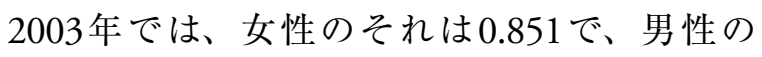
0.826よりもわずかに高い（Elsevier, 2020）。ま た、女性の学術論文の $9 \%$ が学際論文の上位 $10 \%$ に属し、男性の $8 \%$ よりもわずかに高い (Elsevier, 2017)。このように、女性研究者の発 表論文は男性よりも少ないわりに数多く引用さ れ、学際研究にも多く貢献し、質の高い研究成 果を上げている。

また、研究開発のジェンダー・ダイバーシ ティを高めることが、イノベーション向上に貢 献することも明らかである。日本政策投資銀行 （2016）によれば、男性のみのチームと男女を含 むチームの共同発明特許の経済価值を比較する
と、ほぼ全ての業種で男女を含むチームの特許 の経済価值の平均の方が高い。

さらに、SDGsで提示される包摂的な社会と 人びとのウェル・ビーイングを実現するために、 人間の心や行動、社会等を探求する人文社会科 学の担う役割はとくに大きい。そして、その学 問の創造性にとって、多様性を確保することは 不可欠である。したがって、女性研究者の活躍 を推進し、多様性を高めることによって、今後 より一層創造的な研究成果をもたらし、包摂的 な社会実現への貢献を期待できるだろう。

\section{参考文献}

男女共同参画学協会連絡会（2017）「第四回科学技術系専門職 の男女共同参画実態調査」.

Elsevier (2017) Gender in the Global Research Landscape.

Elsevier (2020) The Researcher Journey Through a Gender Lens.

Futagami, Shiho (2010) Non-Standard Employment in Japan: Gender Dimensions, International Institute for Labour Studies, International Labour Organization, 200, pp.1-20.

Futagami, Shiho and Helms, M. Marilyn (2017) Can Women Avoid the Rice Paper Ceiling?: A SWOT Analysis of Entrepreneurship in Japan, SAM Advanced Management Journal, Vol. 82, No. 2, Spring, pp. 40-52.

二神枝保（2020a）「女性研究者比率および指導的地位の女性研 究者比率が低い理由と改善策」人文社会科学系学協会男女 共同参画推進連絡会 (GEAHSS) /調査企画委員会・調査 分析委員会『人文社会科学系研究者の男女共同参画実態調 査（第1回）報告書』, pp. 135-150.

二神枝保 (2020b)『雇用・人材開発の日欧比較: ダイバーシティ \&インクルージョンの視点からの分析』中央経済社.

科学研究者の環境に関する調査研究会 (1997)「科学研究者の 環境に関する調査」.

文部科学省（2019）「令和元年度学校基本調査」.

日本政策投資銀行（2016）「女性の活躍は企業パフォーマンス を向上させる」.

OECD (2018) Main Science and Technology Indicators.

Sachs, J., Schmidt-Traub, G., Kroll, C., Lafortune, G., Fuller, G., Woelm, F. (2020) The Sustainable Development Goals and COVID-19: Sustainable Development Report 2020, Cambridge University Press.

総務省統計局 (2019)「2019年科学技術研究調査結果」.

United Nations (2015) Transforming our world: The 2030 Agenda for Sustainable Development.

World Economic Forum (2019) Global Gender Gap Report 2020. 